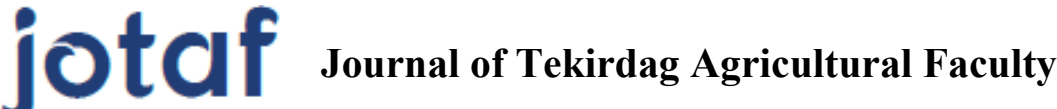

Ocak/January 2021, 18(2)

Başvuru/Received: 25/11/20

Kabul/Accepted: $28 / 01 / 21$

Tekirdağ Ziraat Fakültesi Dergisi

http://dergipark.gov.tr/jotaf

http://jotaf.nku.edu.tr/

ARAŞTIRMA MAKALESI

RESEARCH ARTICLE

\section{Siyah Alaca Süt Sığırlarında Mevsim ve Laktasyon Sırasının Sütün Bileşimi ve Kalitesine Etkisi}

The Effects of Season and Lactation Number on The Composition and Quality Of Holstein Cattle Raw Milk

\section{Ahmet Refik ÖNAL ${ }^{1 *}$, Mahmut ÖZKAN $^{2 * *}$, Yahya Tuncay TUNA ${ }^{3}$}

\section{Özet}

$\mathrm{Bu}$ araştırmada, Siyah Alaca ırkı süt sığırlarından elde edilen sütlerin Somatik Hücre sayıları (SHS) tespit edilerek, SHS'nın mevsim ve laktasyon sırasına göre değişimi ile süt verimi ve süt kalitesine etkisinin araştırılması amaçlanmıştır. Bu amaçla 30 baş sağmal ineğin bir yıl boyunca her ay alınan sütleri değerlendirilmiştir. Alınan süt örnekleri $250 \mathrm{ml}$ 'lik numune kaplarına doldurulmuş ve $+4 \mathrm{C}$ soğuk zincir ile laboratuvara götürülerek analiz edilmiştir. Çalışma kapsamında süt örneklerinin protein, yağ, kuru madde, laktoz, oranları ve Somatik Hücre Sayıları Bentley Merkim Nexgen Series Model 1 cihazı ile otomatik olarak yapılmıştır. Laktasyon sırasına göre süt bileşenlerinden oransal yağ, protein, kurumadde ve ortalama günlük verimleri arasında istatistik olarak fark olmadığı gözlenmiştir ( $p>0.05$ ). Laktasyon sırasına göre sütlerin \% laktoz ve SHS içerikleri bakımından istatistik fark olduğu gözlenmiştir $(\mathrm{p}<0.01)$. Sütlerin SHS içerikleri incelendiğinde en yüksek SHS 4. laktasyon $(928.30 \pm 117.93)$ ve en düşük SHS içeriğine sahip sütlerin 1. laktasyondaki (356.47 \pm 50.55$)$ hayvanlardan elde edildiği, yine mevsime göre SHS içerikleri en yüksekten en düşüğe sırasıyla kış (1003.88 83.53 ), ilkbahar (877.63 \pm 97.43$)$, sonbahar $(575.81 \pm 63.97)$ ve yaz $(212.36 \pm 17.94)$ mevsimlerine ait olduğu gözlenmiştir. SHS ile süt verimi arasında tüm gruplarda negatif yönlü bir ilişki olduğu ve 2., 3. ve 4. laktasyonda ise bu ilişkinin önemli olduğu gözlenmiştir $(p<0.01)$. Araştırma sonucunda, laktasyon sırası ve mevsime göre Siyah Alaca ırkı sığırlarda SHS ile süt verimi arasında genel olarak negatif yönlü bir ilişki olduğu, bu ilişkinin 1. Laktasyon ve yaz mevsimi hariç diğer tüm guruplarda önemli düzeyde olduğu belirlenmiştir. Çiğ sütlerin SHS içerikleri değerlendirildiğinde 1. laktasyon grubu ile yaz mevsimi gurubu hariç diğer tüm gruplarda Türk Gıda Kodeksi Çiğ Süt Tebliği'ne göre belirtilen eşik değerin üzerinde olduğu gözlenmiştir.

Anahtar Kelimeler: Somatik Hücre Sayısı, Siyah Alaca, Süt Kalitesi, Süt Verimi, Süt İçeriği

\footnotetext{
1*Sorumlu Yazar/Corresponding Author: Ahmet Refik Önal, Namık Kemal Üniversitesi Ziraat Fakültesi Zootekni Bölümü 59030 Tekirdağ-Türkiye.E-mail: aronal@nku.edu.tr(DOrcID: 0000-0002-9125-7412

${ }^{2}$ Mahmut ÖZKAN, Namık Kemal Üniversitesi Fen Bilimleri Enstitüsü Zootekni ABD 59030 Tekirdağ-Türkiye. E-mail: m_ozkan_@hotmail.com (DDOrcID: 00000002-3730-2286

${ }^{3}$ Yahya Tuncay TUNA, Namık Kemal Üniversitesi Ziraat Fakültesi Zootekni Bölümü 59030 Tekirdağ-Türkiye. E-mail: yttuna@nku.edu.tr@DorcID: 0000-00024074-2282.

Atıf/Citation:Önal A.R., Özkan M., Tuna Y.T. Siyah Alaca Süt Sı ̆̆ılarında Mevsim ve Laktasyon Sırasının Sütün Bileșimi ve Kalitesine Etkisi. Tekirdağ Ziraat Fakültesi Dergisi, 18 (2), 368-374.
}

\footnotetext{
**Bu çalışma Yüksek Lisans tezinden özetlenmiştir.
}

CBu çalışma Tekirdağ Namık Kemal Üniversitesi tarafından Creative Commons Lisansı (https://creativecommons.org/licenses/by-nc/4.0/) kapsamında yayınlanmıştır. Tekirdağ 2021 


\begin{abstract}
The aim of this study was to determine the Somatic Cell Count of raw milk which obtained from Holstein-Frisian dairy cow milk and determine the effects of season and lactation number on the composition and quality of raw milk. Milk samples were collected monthly during one year from 30 Holstein-Frisian dairy cow. The fresh milk samples were collected in $250 \mathrm{ml}$ flasks and delivered to laboratory at a temperature of $4{ }^{\circ} \mathrm{C}$ cold chain and analyzed. The fat, protein, lactose, dry matter rate and Somatic Cell Count of raw milk samples were automatically performed with Bentley Merkim Nexgen Series Model 1 device. While no significant differences were found in $\%$ fat, $\%$ protein, $\%$ dry matter and average daily milk according to lactation number $(\mathrm{p}>0.05)$, The differences determined in \%lactose and SCC $(\mathrm{p}<0.01)$ were significant. The highest SCC content of raw milk was observed in the 4th lactation $(928.30 \pm 117.93)$ and lowest in 1st lactation (356.47 \pm 50.55$)$. According to the seasons the SCC observed from highest to lowest were in winter $1003.88 \pm 83.53$, in spring $877.63 \pm 97.43$, in autumn $575.81 \pm 63.97$ and in summer $212.36 \pm 17.94$. Negative correlation coefficients observed between SCC and daily milk yield of all lactations, however the correlation coefficient in first lactation was not significant different from 0 . The study indicated, that were negative relationships between SCC and daily milk yield, except in first lactation and summer. It has been observed that all groups of SCC are above the threshold value specified in the Turkish Food Codex Raw Milk notification, except 1 st lactation and the summer.
\end{abstract}

Keywords: Somatic Cell Count, Holstein, Milk Quality, Milk yield, Milk composition 


\section{Giriş}

Günümüzde çoğu gelişmiş ülkede, somatik hücre sayısı süt kalitesinin ölçüsü olarak kullanılmaktadır. Somatik hücre sayısı mastitis kontrolü ve meme sağlığının ıslahı için dolaylı bir özellik olarak ele alınmaktadır. Sütteki somatik hücre sayısını etkileyen önemli neden memenin enfeksiyonudur. Bunun dışında laktasyon dönemi, mevsim, yaş, laktasyon sırası gibi faktörler de SHS üzerine etki eden faktörlerdir. Koç (2004) yaptığı çalışmada laktasyonun başlangıç ayındaki hayvanlardan elde edilen sütlerdeki SHS miktarının diğerlerine göre biraz daha yüksek olduğunu bildirmiştir. Kennedy ve ark. (1982) ile Gökçe (2011) tarafından yapılan çalışmalarda SHS'nın laktasyonun başlarında en yüksek seviyede olduğu, daha sonra yirmi beşinci ve kırk beşinci günler arasında hızla düştüğü ve laktasyonun sonuna kadar bir artış eğiliminde olduğu bildirilmiştir. Şahin ve Kaşıcçı (2014), artan SHS'nın süt laktoz, protein ve YKM içeriğini anlamlı olarak etkilediğini bildirmişlerdir. Özdede (2009), farklı mevsimlerdeki SHS'lar arasındaki farklılığın önemli olduğunu bildirmiştir. Kaşıkcı (2012) yapmış olduğu bir çalışmada sütün laktoz içeriği ile SHS arasındaki ilişkinin negatif yönde anlamlı olduğunu bildirirken, protein ve SHS arasındaki ilişkinin önemsiz olduğunu bildirmiştir. Aynı çalışmada sütün kuru madde ve protein içeriği ile SHS arasındaki ilişkinin negatif yönlü olduğunu bildirmiştir.

Çiğ süt kalite kriterlerinden biri olan Somatik Hücre Sayısının Türk Gıda Kodeksinin (TGK) 2000/6 No’lu “Çiğ Süt ve Isıl İşlem Görmüş İçme Sütleri” Tebliği’ne göre çiğ inek sütlerinin bir ml'sindeki somatik hücre sayısının $500.000 \mathrm{ad} / \mathrm{ml}$ ve altında olması gerektiği bildirilmektedir (Anonim, 2000).

Yapılan bu çalışmada Siyah Alaca ırkı ineklerden elde edilen sütlerin SHS içerikleri tespit edilerek, SHS'nın laktasyon sırası ve mevsime göre değişimi ortaya konarak sütün besin madde içerikleri ile süt verimi arasındaki ilişki incelenmiştir.

\section{Materyal ve Metot}

Çalışmada, Siyah Alaca ırkı süt sığırlarına sahip bir işletmede 30 baş ineğe ait süt örnekleri değerlendirilmiştir. İşletmeden bir yıl boyunca ayda bir kez akşam sütlerinden numune alınmıştır. Alınan süt örnekleri 250 ml'lik numune kaplarına doldurulmuş ve $+4 \mathrm{C}$ soğuk zincir ile laboratuvara götürülerek analiz edilmiştir.

Protein, kuru madde, yağ, laktoz ve somatik hücre sayıları Bentley Nexgen serisi Model 1 cihazı ile otomatik olarak yapılmıştır (Anonim, 2020). Araştırmadan araştırma verilerinin değerlendirilmesinde SPSS (15.0) yazılımı kullanılmıştır. Özelliklere ilişkin tanımlayıcı istatistikler ve pearson korelasyon katsayıları hesaplanmıştır. Laktasyon sırası ve mevsimin etkisinin analizinde ANOVA kullanılmıştır. Çoklu karşılaştırmalar ise Duncan testi ile yapılmıştır.

\section{Araştırma Bulguları ve Tartışma}

\subsection{Laktasyon strasının etkisi}

Laktasyon sırasına göre Siyah Alaca ırkı ineklerden elde edilen verilere ilişkin tanımlayıcı istatistikler Tablo l'de verilmiştir.

Laktasyon sırasına göre süt bileşenlerinden yağ, protein, kurumadde oranları ve günlük süt miktarları arasında istatistik fark olmadığı gözlenmiştir ( $>$ >0.05).Laktasyon sırasına göre Siyah Alaca sığırları için sütün içerdiği en

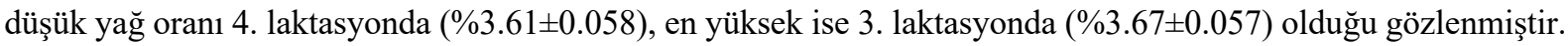
En yüksek protein ve kurumadde içerikleri sırasıyla 3 laktasyon (\%3.30 \pm 0.034$)$ ve 4.laktasyondaki $(\% 13.04 \pm 0.108)$ hayvanlardan elde edilen sütlerde olduğu belirlenmiştir. Laktasyon sırasına göre sütlerin laktoz ve SHS içerikleri bakımından istatistik farkın önemli olduğu gözlenmiştir $(\mathrm{p}<0.01)$. Laktoz içeriği en yüksek 2. laktasyon

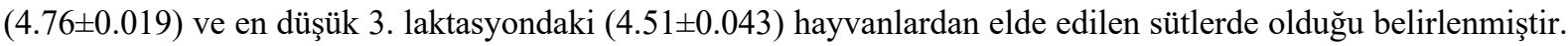

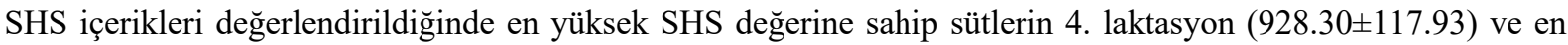

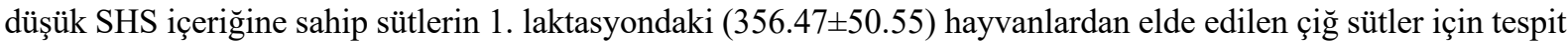
edilmiştir. Araştırıcılar, laktasyon sırasının artması ile SHS'nında artış gösterdiğini bildirmişlerdir (Schutz ve ark., 1990; Göncü ve Özkütük, 2002; Çoban ve ark. 2007). Çalışmada elde edilen sonuçlar literatür kaynaklarında 
JOTAF/ Journal of Tekirdag Agricultural Faculty, 2021, 18(2)

belirtilen sonuçlar ile uyumludur. Eyduran ve ark. (2005) yaptıkları bir çalışmada SHS' nın 3. laktasyondaki hayvanlarda yüksek olduğunu bildirmiş ve yüksek olmasını ise bu hayvanların subklinik mastitis hastalığına yakalanma riskinin daha yüksek olması ile ilişkilendirmiştir. Bu sonuç bizim çalışmamızda elde edilen sonuçlar ile benzerlik göstermemektedir.

Tablo 1. Sütlerin laktasyon sırasına göre içeriklerine ilişkin ortalama \pm standart hatalart

Table 1. Means \pm standard errors of milk yield and milk components acording to lactation numbers

\begin{tabular}{clccccc}
\hline $\begin{array}{c}\text { Laktasyon } \\
\text { Sirası }\end{array}$ & $\mathrm{n}$ & Yağ (\%) & $\mathrm{n}$ & Protein (\%) & $\mathrm{n}$ & Laktoz (\%) \\
\hline $\mathrm{P}$ & & 0.830 & & 0.496 & & 0.001 \\
1 & 47 & $3.61 \pm 0.081$ & 46 & $3.25 \pm 0.044$ & 47 & $4.72 \pm 0.031 \mathrm{c}$ \\
2 & 177 & $3.66 \pm 0.045$ & 170 & $3.25 \pm 0.023$ & 178 & $4.76 \pm 0.019 \mathrm{c}$ \\
3 & 108 & $3.67 \pm 0.057$ & 103 & $3.30 \pm 0.034$ & 107 & $4.51 \pm 0.043 \mathrm{a}$ \\
4 & 91 & $3.61 \pm 0.058$ & 86 & $3.29 \pm 0.034$ & 92 & $4.63 \pm 0.028 \mathrm{~b}$ \\
Toplam & 423 & $3.65 \pm 0.028$ & 405 & $3.27 \pm 0.016$ & 424 & $4.66 \pm 0.016$ \\
\hline Laktasyon & $\mathrm{n}$ & Kurumadde & & $\mathrm{SHS}$ & & Süt Verimi \\
Sirasi & & $(\%)$ & $\mathrm{n}$ & $(* 1000 \mathrm{ad} / \mathrm{ml})$ & $\mathrm{n}$ & $($ litre/gün) \\
\hline $\mathrm{P}$ & & 0.335 & & 0,001 & & 0,130 \\
1 & 47 & $12.70 \pm 0.138$ & 47 & $356.47 \pm 50.55 \mathrm{a}$ & 47 & $23.87 \pm 0.196$ \\
2 & 179 & $12.96 \pm 0.090$ & 178 & $509.48 \pm 42.81 \mathrm{a}$ & 179 & $23.69 \pm 0.119$ \\
3 & 108 & $12.84 \pm 0.113$ & 104 & $841.15 \pm 86.83 \mathrm{~b}$ & 108 & $24.06 \pm 0.183$ \\
4 & 92 & $13.04 \pm 0.108$ & 89 & $928.30 \pm 117.93 \mathrm{~b}$ & 92 & $24.10 \pm 0.127$ \\
Toplam & 426 & $12.92 \pm 0.055$ & 418 & $663.97 \pm 39.44$ & 426 & $23.89 \pm 0.077$ \\
\hline
\end{tabular}

* Aynı sütunda yer alan ve aynı harfi taşıyan değerler arasında fark önemli değildir ( $>0.05)$

\subsection{Mevsimin etkisi}

Mevsime göre süt bileşenlerinden süt yağı, süt proteini, süt kurumaddesi, SHS ve ortalama günlük verimleri arasında $(\mathrm{p}<0.01)$ ve laktoz içerikleri bakımından $(\mathrm{p}<0.05)$ istatistik önemli fark olduğu gözlenmiştir $($ Tablo 2).

Tablo 2. Sütlerin mevsime göre içerikleri

Table 2. Composition of raw milk acording to seasons

\begin{tabular}{|c|c|c|c|c|c|c|}
\hline $\begin{array}{l}\text { Laktasyon } \\
\text { Sirası }\end{array}$ & $\mathrm{n}$ & $\begin{array}{l}\text { Yağ } \\
(\%)\end{array}$ & $\mathrm{n}$ & $\begin{array}{c}\text { Protein } \\
(\%)\end{array}$ & $\mathrm{n}$ & $\begin{array}{r}\text { Laktoz } \\
(\%)\end{array}$ \\
\hline $\mathrm{P}$ & & 0,001 & & 0,001 & & 0,05 \\
\hline Sonbahar & 103 & $3.44 \pm 0.058 b$ & 105 & $3.17 \pm 0.030 \mathrm{a}$ & 106 & $4.73 \pm 0.036 b$ \\
\hline $\mathrm{K}_{1 S ̧}$ & 97 & $3.66 \pm 0.050 \mathrm{a}$ & 86 & $3.46 \pm 0.031 \mathrm{c}$ & 95 & $4.59 \pm 0.037 \mathrm{a}$ \\
\hline İlkbahar & 117 & $3.75 \pm 0.062 \mathrm{a}$ & 112 & $3.26 \pm 0.033 b$ & 117 & $4.66 \pm 0.031 \mathrm{ab}$ \\
\hline Yaz & 106 & $3.72 \pm 0.048 \mathrm{a}$ & 102 & $3.22 \pm 0.024 \mathrm{ab}$ & 106 & $4.66 \pm 0.021 \mathrm{ab}$ \\
\hline Toplam & 423 & $3.65 \pm 0.028$ & 405 & $3.27 \pm 0.016$ & 424 & $4.66 \pm 0.016$ \\
\hline $\begin{array}{l}\text { Laktasyon } \\
\text { Sirası }\end{array}$ & $\mathrm{n}$ & $\begin{array}{l}\text { Kurumadde } \\
(\%)\end{array}$ & $\mathrm{n}$ & $\begin{array}{l}\text { SHS }(* 1000 \\
\mathrm{ad} / \mathrm{ml})\end{array}$ & $\mathrm{n}$ & $\begin{array}{l}\text { Ort. Günlük } \\
\text { Süt Verimi } \\
\text { (litre/gün) }\end{array}$ \\
\hline $\mathrm{P}$ & & 0,01 & & 0,001 & & 0,001 \\
\hline Sonbahar & 106 & $12.35 \pm 0.094 \mathrm{a}$ & 102 & $575.81 \pm 63.97 b$ & 106 & $24.20 \pm 0.163 a$ \\
\hline $\mathrm{K}_{1 S ̧}$ & 97 & $12.94 \pm \mathrm{b} 0.082$ & 95 & $1003.88 \pm 83.53 \mathrm{c}$ & 97 & $23.56 \pm 0.144 b$ \\
\hline İlkbahar & 117 & $13.50 \pm 0.103 \mathrm{c}$ & 115 & $877.63 \pm 97.43 c$ & 117 & $23.56 \pm 0.120 b$ \\
\hline Yaz & 106 & $12.83 \pm 0.123 b$ & 106 & $212.36 \pm 17.94 \mathrm{a}$ & 106 & $24.25 \pm 0.174 a$ \\
\hline Toplam & 426 & $12.92 \pm 0.055$ & 418 & $663.97 \pm 39.44$ & 426 & $23.89 \pm 0.077$ \\
\hline
\end{tabular}

** Aynı sütunda yer alan ve aynı harfi taşıyan değerler arasında fark önemli değildir ( $>0.05$ ) 
Mevsime göre sütlerin en düşük süt yağ içeriği sonbahar mevsiminde (3.44 \pm 0.058$)$ ve en yüksek yaz mevsiminde $(3.72 \pm 0.048)$ olduğu gözlenmiştir. En yüksek \% protein ve \% kurumadde içerikleri sirasıyla kış mevsimi (3.464 \pm 0.031$)$ ve ilkbahar mevsiminde (13.50 \pm 0.103$)$ hayvanlardan elde edilen sütlerde olduğu belirlenmiştir. Mevsimlere göre sütlerin SHS içerikleri en yüksekten en düşüğe sırasıyla kış (1003.88 \pm 83.53$)$, ilkbahar (877.63 \pm 97.43$)$, sonbahar $(575.81 \pm 63.97)$ ve yaz $(212.36 \pm 17.94)$ mevsimlerine ait olduğu gözlenmiştir. Ortalama günlük süt verimleri değerlendirildiği yıllık ortalamanın (23.89 \pm 0.077$)$ olduğu gözlenmiştir. Araştırmacılar en yüksek SHS değerlerinin yaz aylarında olduğunu bildirmişlerdir (Göncü, 2000; Göncü ve Özkütük, 2002; Eyduran ve ark., 2005; Özdede, 2009; Gökçe, 2011; Aytekin ve Boztepe, 2014).

$\mathrm{Bu}$ araştırmada ise mevsime göre süt SHS içeriği en düşük ortalamaların yaz mevsiminde olduğu gözlenmiştir. Özdede (2009)'nin aktardığına göre Çoban ve ark. (2007)'nın yaptıkları çalışmada ineklerden kış mevsiminde alınan sütlerde, yaz mevsiminde alınan sütlere göre göre daha yüksek somatik hücre sayısına sahip olduklarını bildirmişlerdir. Araştırmada kış mevsimindeki SHS'ndaki artışın hayvanların yazın meradan aldıkları epitelyum koruyucu özelliği olan vitamın A’yı yeterince alamadıklarından kaynaklı olabileceğini bildirmişlerdir. Belirtilen sonuçlar araştırma sonuçları ile uyum göstermektedir.

\subsection{SHS ile süt bileșenleri arașındaki ilişki}

Laktasyon sırası ve mevsime göre Siyah Alaca ırkından elde edilen sütlerdeki SHS içeriği ile süt verim ve bileşenleri arasındaki ilişkinin belirlenmesi için hesaplanan korelasyon katsayıları aşağıdaki Tablo 3'te verilmiştir. Laktasyon sırasına göre birinci, ikinci, üçüncü ve dördüncü laktasyon gruplarında SHS ile süt yağ oranı arasındaki ilişki sırasıyla $\mathrm{r}=-0.14, \mathrm{r}=-0.04, \mathrm{r}=0.15$ ve $\mathrm{r}=-0.12$ olarak hesaplanmış olup ilişkinin önemsiz olduğu gözlenmiştir $(\mathrm{p}>0.05)$. 3. Laktasyondaki hayvanlarda SHS ile süt protein oranı arasındaki ilişkinin pozitif yönlü $(r=0.35)$ ve önemli olduğu gözlenmiştir ( $<<0.01)$. SHS ile laktoz içerikleri arasındaki ilişkinin tüm gruplar için önemli olduğu gözlenmiştir $(p<0.01)$. SHS ile kurumadde arasındaki ilişkinin düşük düzeyde olduğu belirlenmiştir $(p>0.05)$. SHS ile günlük süt miktarı arasında tüm gruplarda negatif yönlü bir ilişki olduğu ve 2., 3. ve 4. laktasyonda ise bu ilişkinin önemli olduğu gözlenmiştir $(\mathrm{p}<0.01)$.

Mevsime göre SHS ile süt yağ oranı arasındaki ilişki yaz, sonbahar, kış ve ilkbahar için sırasıyla r=0.17, r=0.13, $\mathrm{r}=-0.00$ ve $\mathrm{r}=-0.13$ olarak hesaplanmış olup ilişkinin istatistiksel olarak önemsiz olduğu gözlenmiştir $(\mathrm{p}>0.05)$. Mevsime göre SHS ile süt protein oranı arasındaki ilişki incelendiğinde yaz $(r=0.54)$ ve ilkbahar $(r=0.32)$ mevsimlerinde önemli bir ilişki olduğu belirlenmiştir $(\mathrm{p}<0.01)$. SHS ile laktoz içerikleri arasındaki ilişki tüm laktasyonlar için negatif yönlü ve önemli olduğu gözlenmiştir $(\mathrm{p}<0.01)$. SHS ile kurumadde içerikleri arasında yaz $(\mathrm{r}=0.60)$ ve sonbahar $(\mathrm{r}=0.20)$ mevsimlerinde önemli bir ilişki gözlenmiş iken $(\mathrm{p}<0.01)$, kış ve ilkbahar mevsimleri için negatif yönlü ve önemsiz olduğu gözlenmiştir.

Somatik hücre sayısı ile süt verimi arasındaki ilişkinin belirlendiği bir çalışmada $r=0.023$ düzeyinde düşük pozitif yönlü ve önemsiz olduğunu (Gökçe, 2011), Schutz ve ark. (1990) SHS ile süt verimi arasında negatif bir ilişski bulunduğunu bildirmişlerdir. Araştırma bulguları ile bu araştırmanın bulguları arasında benzerlik olduğu gözlenmiştir. Şahin ve ark. (2014) Anadolu Mandalarında yaptıkları çalışmada SHS ile yă̆, protein ve asitlik arasındaki ilişkinin pozitif yönde ve önemli olduğu bildirilmiştir. Önal ve Özder (2007) tank sütü SHS ile süt yağ, süt protein, yağsız kuru madde ve toplam bakteri içeriği arasındaki fenotipik korelasyon katsayıları sırasıyla $\mathrm{r}=0.036, \mathrm{r}=0.421, \mathrm{r}=0.251, \mathrm{r}=0.219$ olarak belirlemiştir (Önal, 2005). 
Tablo 3. Laktasyon Sırası ve Mevsime göre SHS ile Süt Verim ve Bileşenleri Arasındaki İlişki

Table 3. Relationship between SCC and milk components according to lactation numbers and season

\begin{tabular}{lcccccc}
\hline & & Yağ $(\%)$ & Protein $(\%)$ & $\begin{array}{l}\text { Laktoz } \\
(\%)\end{array}$ & $\begin{array}{c}\text { Kurumadde } \\
(\%)\end{array}$ & $\begin{array}{c}\text { Ort. Günlük Süt } \\
\text { Verimi } \\
\text { (litre/gün) }\end{array}$ \\
\hline \multirow{3}{*}{ Laktasyon } & 1 & -0.14 & $0.32^{*}$ & $-0.63^{* *}$ & 0.06 & -0.18 \\
Sirasi & 2 & -0.04 & -0.01 & $-0.30^{* *}$ & -0.01 & $-0.47^{* *}$ \\
& 3 & 0.15 & $0.39^{* *}$ & $-0.33^{* *}$ & 0.17 & $-0.50^{* *}$ \\
& 4 & -0.12 & $0.35^{* *}$ & $-0.45^{* *}$ & 0.15 & $-0.26^{*}$ \\
\hline \multirow{6}{*}{ Mevsim } & Yaz & 0.17 & $0.54^{* *}$ & $-0.67^{* *}$ & $0.60^{* *}$ & -0.18 \\
& Sonbahar & 0.13 & 0.01 & $-0.20^{*}$ & $0.20^{*}$ & $-0.42^{* *}$ \\
& Kiş & -0.00 & 0.04 & $-0.42^{* *}$ & -0.14 & $-0.36^{* *}$ \\
& Illkbahar & -0.13 & $0.32^{* *}$ & $-0.55^{* *}$ & -0.07 & $-0.34^{* *}$ \\
\hline
\end{tabular}

$* * \mathrm{P}<0.01 \quad * \mathrm{P}<0.05$

\section{Sonuç}

Araştırma sonucunda, laktasyon sırası ve mevsime göre Siyah Alaca ırkı sığırlarda SHS ile süt verimi arasında genel olarak negatif yönlü bir ilişki olduğu, bu ilişkinin 1. laktasyon ve yaz mevsimi hariç diğer tüm gruplarda önemli düzeyde olduğu belirlenmiştir. Çiğ sütlerin SHS içerikleri değerlendirildiğinde 1. laktasyon grubu ile yaz mevsimi gurubu hariç diğer tüm gruplarda belirlenen SHS içerikleri Türk Gıda Kodeksi (TGK) 2000/6 No'lu “Çiğ Süt ve Isıl İşlem Görmüş İçme Sütleri” Tebliği’ne göre belirtilen eşik değerin üzerinde olduğu gözlenmiş olup bu durumun da önemli bir kalite sorunu olarak öne çıktığı söylenebilir. SHS dünyada çiğ süt kalite kriteri olarak kullanılan en önemli faktörlerden biridir. Ülkemiz de dünyaca kabul edilen ve olması gereken eşik değerlerin yakalanabilmesi için öncelikle üreticilerin meme ve sağım hijyeni konularında bilinçlendirilmesi ve hijyen kurallarına uyulması gerektiği söylenebilir. 


\section{Kaynakça}

Anonim (2000). Türk Gıda Kodeksi, Çiğ Süt ve Isıl İşlem Görmüş İçme Sütleri Tebliği. Tebliğ No:2000/6.

Anonim (2020). About Bentley Instruments. ftp://ftp.bentleyinstruments.com/ Marketing/ BentleyFTS/ Bentley Next Genfinal.pdf (Erişim tarihi:24.11.2020).

Aytekin, İ., Boztepe, S. (2014). Süt Sığırlarında Somatik Hücre Sayısı, Önemi ve Etki Eden Faktörler, Türk Tarım Gıda Bilim ve Teknoloji Dergisi, (2): 112-121.

Çoban, Ö., Sabuncuoğlu, N., Tüzemen, N. (2007). Siyah Alaca ve Esmer ineklerde somatik hücre sayısına çeşitli faktörlerin etkisi. Lalahan Hay. Araş. Ens. Derg, 47, 15-20.

Eyduran, E., Özdemir, T., Yazgan, K., Keskin, S. (2005). Siyah Alaca İnek Sütündeki Somatik Hücre Sayısına Laktasyon Sırası ve Dönemin Etkisi, YYÜ Vet Fak Derg. 2005, 16 (1):61-65

Gökçe, G. (2011). Çukurova Bölgesi Entansif Süt Sığırı İşletmelerindeki İlkine Doğuran Siyah Alacalarda Somatik Hücre Sayısına Etki Eden Bazı Tip, Sağım ve Amanejman Özelllikleri Arası İlişkiler, (Doktora Tezi), Çukurova Üniversitesi Fen Bilimleri Enstitüsü Adana

Göncü, S. (2000). Adana Entansif Süt Siğırcılı̆̆ı İşletmelerinde Yetiştirilen Saf ve Melez Siyah Alaca Inek Sütlerinde Somatik Hücre Sayısına Etki Eden Faktörler ve Mastitis İle İlişkisi, (Doktora Tezi), Çukurova Üniversitesi Fen Bilimleri Enstitüsü Adana

Göncü, S., Özkütük, K. (2002). Adana Entansif Süt Sığırcılığı İşletmelerinde Yetiştirilen Saf ve Melez Siyah Alaca İnek Sütlerinde Somatik Hücre Sayısına Etki Eden Faktörler ve Mastitis ile İlişkisi, Hayvansal Üretim 43(2): 44-53 (2002)

Kaşıkcı, M. (2012). Sivas İli Yıldızeli İlçesinde Halk Elinde Yetiştirilen Esmer Sığırların Çiğ Süt Kompozisyonu ve Somatik Hücre Sayısının Belirlenmesi, (Yüksek Lisans Tezi), Gaziosmanpaşa Üniversitesi Fen Bilimleri Enstitüsü Tokat

Kennedy, B W., Sethar, M S., Moxley, J E., Downwy, B R. (1982). Heritability of somatic cell count and its relationship with milk yield and composition in Holsteins. Journal of Dairy Science, 65, 843-847.

Koç, A. (2004). Aydın'da yetiştirilen Siyah-Alaca ve Esmer ırkı sığırlarda sütteki somatik hücre sayısının değişimi. 4.Ulusal Zootekni Kongresi. 1-3 Eylül. SDÜ Z.F. Zootekni Bölümü, Isparta

Önal, A R. (2005) Trakya'da Özel Bir Süt Isşleme Tesisi Tarafindan Değerlendirilen Çiğ Sütlerin Somatik Hücre Sayısı ve Bazı Bileşenlerinin Tespiti, (Yüksek Lisans Tezi), Trakya Üniversitesi Fen Bilimleri Enstitüsü, Edirne

Önal, A R., Özder, M. (2007). Trakya'da özel Bir Süt İşleme Tesisi Tarafindan Değerlendirilen Çiğ Sütlerin Somatik Hücre Sayisi ve Bazi Bileşenlerinin Tespiti. Tekirdağ Ziraat Fak. Derg. 4(2): 195-199.

Özdede, F. (2009). Ankara İli Süt Sı̆̆ırı Yetiştiricileri Birliğine Üye Süt Siğırı Isşletmelerinde Üretilen Sütlerin Somatik Hücre Sayıları, (Yüksek Lisans Tezi), Ankara Üniversitesi. Fen Bilimleri Enstitüsü Ankara

Sahin, A., Yıldırım, A., Ulutas, Z. (2014). Anadolu Mandalarında Bazı Çiğ Süt Parametreleri ile Somatik Hücre Sayısı Arasındaki İlişkiler. Tekirdağ Ziraat Fak. Derg. 11 (1), 114-121

Schutz, M M., Hansen, L B., Steuernagel, G. R., Kuck, A. L. (1990). Variation of Milk Fat, Protein and Somatic Cells for Dairy Cattle. Journal of Dairy Science, Vol 73 No 2

Şahin. A., Kaşıkçı, M. (2014) Esmer İneklerde Somatik Hücre Sayısı ve Bazı Çiğ Süt Parametreleri Arasındaki İlişkilerin Belirlenmesi, Turkish Journal of Agriculture - Food Science and Technology 2(5):220 